\title{
Kalla yarning at Matagarup: Televised legitimation and the limits of heritage-making in the city
}

\author{
Thor Kerr \\ Curtin University \\ Thor.Kerr@curtin.edu.au \\ Shaphan Cox \\ Curtin University \\ $\underline{\text { S.Cox@ curtin.edu.au }}$
}

\begin{abstract}
Copyright@ 02017 Thor Kerr \& Shaphan Cox. This text may be archived and redistributed both in electronic form and in hard copy, provided that the author and journal are properly cited and no fee is charged, in accordance with our Creative Common Licence.
\end{abstract}

\begin{abstract}
This paper is directed towards furthering understandings of popular television news reporting on Aboriginal solidarity gatherings at Matagarup on Heirisson Island, a state-registered Aboriginal Heritage Site in Perth, Western Australia. In doing so, it also seeks to identify the practical limits of heritage making in disrupting the legitimization of state action not recognizing such heritage claims. In 2012 and 2015, Aboriginal citizens gathering and camping at the heritage site were subject to police raids legitimized by popular media organizations reporting a breach of municipal bylaws prohibiting camping and fires on Heirisson Island. This paper examines a shift in popular television reporting over the three years towards acknowledging that Aboriginal people should be able to assemble, without police harassment, around a fire at the site. The most radical shift in reporting is observable in Nine News coverage of events. For this reason, eight televised items from Nine News in 2015 are analysed alongside Nine News reporting described in the authors' previous study of reporting of events at Matagarup in 2012. The paper identifies and discusses the implications of two key dialogical processes in the news production: Firstly, a process of cross-cultural reading and shared understandings of fire as hearth, and secondly a process of reproducing a dominant discursive tradition locating home for Aboriginal people outside the city.
\end{abstract}

Keywords: Fire as hearth, Aboriginal Tent Embassy, dialogic 
This paper is part of a broader project that began in 2012 when the Nyoongar Tent Embassy invited Curtin University to investigate how its gatherings at Matagarup (Heirisson Island) in Perth were being criminalized in popular news reports. Through this project, the authors along with other partners have produced a book on the systemic criminalization of the tent embassy by popular media organizations (Kerr \& Cox 2013), an exhibition disrupting the criminal image of Aboriginal activists in Perth (Creagh, Ryder, Cox \& Kerr 2013) and a paper demonstrating that Western Australia's largest commercial media organisation, Seven West Media, acts in the interest of its holding company in undermining the legitimacy of Aboriginal heritage claims through its news reporting and editorial publication (Kerr \& Cox 2016; Thomson, Bennett, Johnston and Mason 2015). In this paper, we turn our attention to a noticeable shift in the reporting of Aboriginal gatherings at Matagarup by Nine News, which claims the greatest share of national television evening news audience ratings (Nine Entertainment Co. Holdings 2014, 11). Eight key media texts produced by Nine News between March 1 and May 1, 2015 relating to an Aboriginal Refugee Camp located at an island adjacent to the Perth CBD are analysed in comparison with findings from the Kerr \& Cox (2013) study of a similar gathering at the same place. This paper identifies two 'outside-in' dialogical processes running through the production of popular media representations, firstly to do with a cross-cultural reading and shared understanding of fire as hearth and secondly, the reproduction of a powerful discursive tradition which locates home for Aboriginal people outside the city. This colonial tradition obstructed popular media representation of kalla yarning (talking around a home fire) as a local contemporary place in the city.

Fire as hearth in the context of this study represents a potential for transformational politics through shared understandings amongst settler and indigenous cultures in Western Australia. An opportunity for popular recognition and respect for Aboriginal sovereignty seemed to occur at the Matagarup Refugee Camp when Nine News Perth (Nine News Perth, March 13, 2015) reported that police had treated the campfire as a safe zone for the people gathered around it during one of their raids to remove the camp. Ten days later, Nine News Perth (Nine News Perth, March 24, 2015) offered its audience an opportunity to move in from outside the camp to share in the fireside stories around a Nyoongar sacred fire. This was an interesting moment in popular media representation because Nine News like other popular news organisations had actively reproduced a discourse of Aboriginality synonymous with illegality in reporting on the previous Aboriginal gathering, the Nyoongar Tent Embassy, at Heirisson Island in 2012. In a study of these media reports, Kerr and Cox (2013) demonstrate how Perth media outlets, notably Nine News, worked to place authority directly in the hands of police and government workers intent on removing an 'illegal' Aboriginal gathering. Popular media reports relied heavily on the construction of a threatening Nyoongar menace while refusing to engage with any reference to Heirisson Island's status as a state-registered Aboriginal Heritage site as a 'meeting place, plant resource, camp, hunting place' (Aboriginal Heritage Enquiry System, 2012). Instead, authorisation was given to City of Perth bylaws prohibiting camping and lighting fires in a public reserve in popular news reports on the tent embassy in 2012. This law-breaker protester frame was maintained across the mainstream news organisations with very little challenge or critical questioning. However, in March 2015 , amid growing public outrage over a government plan to close 150 remote Aboriginal communities, there seemed to be an opportunity for popular news media to represent the island as an Aboriginal place - recognised in state, national and 
international law. This public mood and apparent police recognition of the fire at the island as sacred may have provided the impetus for the Nine News media team to spend the night there ten days later (Nine News Perth, March 24, 2015).

\section{Fire as a home-making technology}

Fire is an important place-making technology that signifies home in both Nyoongar culture and in the popular culture of invading settlers. As British settlers secured their hold over Nyoongar country in the 1830s through militia raids that ended the lives and home fires of Aboriginal people (Statham-Drew 2003), Charles Dickens was writing the texts in London that would place the 'roaring fire of the domestic hearth' at the symbolic centre of his novels (Buckland 2009), a significant node of popular modern English storytelling. Dickens' fireside was read as 'an idyllic space of conflict resolution' in a city of problems, according to Buckland, and the attraction of the fireside transcended class divisions (2009).

With Dickens' novels, readers could empathise with the orphaned, displaced and disowned individuals yearning to get closer to the blazing fires of home (Buckland 2009). Fire was a symbol for shared experience and harmony in the minds of British readers, presumably including the settlers arriving on the shores of Nyoongar country. Fire continued to hold a special place in the minds of modern readers even after the advent of electricity. This is evident in the importance given to the domestic hearth while suppressing the overtness of electric lighting and heating in Le Corbusier's studio residences (Willmert 2006). Fireplaces were used to define individual retreats and places of communal gathering in the home, partly because they can be seen as engendering and reinforcing creativity. Despite a shared understanding of fire as hearth, the use of fire by Aboriginal people as a practice of sovereignty has tended to be overlooked in popular media reports and commentary (Vincent 2006, 14). Sacred fire and smoking ceremonies have been central and important features in the representation of justice claims, decolonization and sovereign right to land for decades at the Aboriginal Tent Embassy in Canberra (Gilbert 2013, 196-201), and its coals have been used to light fires for similar purposes at other embassies such as the 1998 declaration of sovereign space in Melbourne (Vincent 2006, 13).

In Nyoongar culture, ' $k a l l a$ ' or ' $k a r l a '$ is at the heart of a range of meanings that have been interpreted into English. 'Kalla' has been interpreted to mean 'fire' but also 'a country, firewood' or 'camp' (Bindon \& Chadwick 2011, 109). It is an important root word for dozens of words: 'kalla-budjor' means 'land, property in'; 'kalleep' means 'one's own country, land or fire'; 'kallip' means 'acquainted with country or people; property in land; knowledge of people and localities'; and 'kalok' means as 'at home, at my camp' (Bindon \& Chadwick 2011, 109-110). In describing the Karla Yarning: Stories of the Home Fires mapping project sponsored by the City of Perth (Jones \& Collard 2014), Professor Len Collard described karla as not just a camp fire but a symbol implying 'the home where people gather to meet around the fire' and yarning as an interrogation, analysis and 'a dialogue around a subject' (Wynne 2014). In Wynne's interview on ABC News, Collard described the relation of karla to the site of this study: 
Karla Yarning is an ancient phenomenon here in the Noongar country around the Derbal Yerrigan, the estuary or the Perth waters but the Karla is a highly symbolic thing and in Noongar it means the campfire, but it also implies and means the home where people gather to meet around the kalla. And kalla also means estate and your estate, your country, the place where you live in and around the traps. Yarning in Noongar really means to interrogate, or to investigate or to analyse, or to have a dialog around a subject... So in this particular project, with the Perth City Council, karla yarning was to interrogate the country, or the fire place of traditional owners in and around the Perth metropolitan area, the Wadjuks. (Wynne 2014).

Besides being an important technology for creativity, kalla is also an important symbol of home and a place of dialogue and problem solving in Noongar imaginaries. Given the domestic hearth's enduring symbolic centrality in popular modern culture and colonial interpretation of kalla in language studies, it is unsurprising that colonial recognition of Noongar home places has been solicited around the kalla fireside (Hallam 1975; Jones \& Collard 2014). The kalla hearth may also provide the aesthetics of an 'unknowable space' onto which non-Aboriginal knowledge of Aboriginal people can be projected in postcolonial Australian imaginaries (Gelder \& Jacobs 2006, 156). After all, fire has been used to solicit a sense of sacredness in memorialising Australian contribution to imperial overseas wars. The 'eternal flame' in Kings Park was placed for sacred-soliciting effect in a 'Pool of Reflection' in the foreground of a crucifix-inscribed obelisk 'overlooking Perth Water' (Botanic Gardens \& Parks Authority 2015). In an ironic performance of the sacred, the flame was inaugurated by Queen Elizabeth II on April Fools' Day 2000. It has burned at the site for 15 years symbolising 'the promise of all Western Australians' to remember dead soldiers (Botanic Gardens \& Parks Authority 2015). While the eternal flame may help Western Australians to forget that the memorial was constructed relatively recently on a much older, and arguably more important, sacred site in Wadjuk country, the flame itself is an empty signifier that can be used for incorporating a variety of claims and desires (Laclau 2005). Although audiences in Western Australia have been encouraged to read the sacredness of imperial war in the 'eternal flame', this encouragement may also help them to recognise the sacredness of Noongar people using smoke and flame in their political gatherings in Perth. In other words, there is an opportunity for media audiences in Western Australia to see Aboriginal people at home and in a sacred place yarning around the kalla fireside at Matagarup, even if they have not been informed that the state has already recognised this as a sacred site for Aboriginal people (Kerr \& Cox 2013).

\section{Authorising heritage-making: A Study of Nine News}

This section will show how popular media representations of Aboriginal gatherings at Matagarup shifted between 2012 and 2015. A review of publically archived media texts between March 1 and May 12015 indicated that Nine News Perth had demonstrated the most empathy with the gathering by the end of this archive period. This was particularly noticeable in a special report (Nine News Perth, March 24, 2015) when Nine News journalist Scott Cunningham spent the night around the 
campfire reporting fireside stories of the gathering at Matagarup. This item and seven other television reports produced by Nine News were analysed for this study (Table 1). The key findings from analysis of the Nine News 2015 archive are described below in relation to the results of our previous study (Kerr and Cox 2013) of popular media reporting on the 2012 gatherings. Three key themes have emerged from this analysis relating to: media representation of a problem to be solved; representation of fire for community making; and, representation of campfire as a temporary aberration, not an enduring home place in the city.

Nine Network has Free to Air television broadcast licences in Perth and Australia's other major cities. The network focuses on the core genres of news, sport, local drama and quality reality. After extending its $6 \mathrm{pm}$ news to one hour in early 2014, Nine Network claims that it has come to dominate 'the all important 6-7pm timeslot' by 'delivering Australians world class and local News and Current Affairs content' (Nine Entertainment Co. Holdings 2014, 11). The composition of this holding company suggests that Nine Network serves broader investment interests than the majority shareholder for Perth's dominant news provider, 7 News, whose main source of income comes from the supply of heavy equipment for mining and other industries (Kerr \& Cox 2016). In light of these sets of corporate interests, it could be argued that Nine News was relatively less constrained in authorising Aboriginal voices and recognising the performance of Aboriginal heritage at Matagarup in its news reports in 2015. The 8 media texts are documented in Table 1 below:

Table 1: Nine News Perth media archive 2015

\begin{tabular}{|c|c|c|}
\hline $\begin{array}{l}\text { Item number and } \\
\text { Date }\end{array}$ & Source & Title \\
\hline 1. 10 March 2015 & $\begin{array}{l}\text { Nine News } \\
\text { Perth }\end{array}$ & Island Stand Off \\
\hline 2. 11 March 2015 & $\begin{array}{l}\text { Nine News } \\
\text { Perth }\end{array}$ & Island Stand Off \\
\hline 3. 13 March 2015 & $\begin{array}{l}\text { Nine News } \\
\text { Perth }\end{array}$ & Island Showdown \\
\hline 4. 17 March 2015 & $\begin{array}{l}\text { Nine News } \\
\text { Perth }\end{array}$ & Heirisson Protest \\
\hline 5. 20 March 2015 & $\begin{array}{l}\text { Nine News } \\
\text { Perth }\end{array}$ & Heirisson Protest \\
\hline 6. 24 March 2015 & $\begin{array}{l}\text { Nine News } \\
\text { Perth }\end{array}$ & $\begin{array}{l}\text { Special Report: Inside } \\
\text { Heirisson }\end{array}$ \\
\hline 7. 30 April 2015 & $\begin{array}{l}\text { Nine News } \\
\text { Perth }\end{array}$ & Show of Force \\
\hline 8. 1 May 2015 & $\begin{array}{l}\text { Nine News } \\
\text { Perth }\end{array}$ & City Protest \\
\hline
\end{tabular}

\section{Setting the Scene: Construction of the Problem}

In 2012 media coverage of the Aboriginal gathering constructed events as a 'problem' caused by Aboriginal 'protestors', a problem which therefore had to be policed. The 
coverage tended to represent Aboriginality as synonymous with criminality and although initial news reports focussed on land and justice claims, the media's framing of news stories quickly shifted to an alleged illegality of camping on the island and the camp's potential for violence. The media frequently represented the Aboriginal participants in negative or problematic ways: by reducing them to illegal protesters; and by silencing them and excluding them from the ordinary right to seek recognition of legal entitlement. Media reports also turned them into lawbreakers through news narrative and visual composition techniques that implicitly encouraged viewer identification with police and state authorities. In 2015, Aboriginal activists recreated the camp at Matagarup but this time not under the banner of Nyoongar Tent Embassy but as an Aboriginal Refugee Camp set up in response to a state-and-federal government policy to shutdown Aboriginal communities. Media reports maintained that the gathering had been camping illegally at Heirisson Island but framed it within the context of a bigger problem of government policy causing Aboriginal homelessness. News Item 1 makes a connection between government plans and the gathering's concerns:

Prime Minister Tony Abbott has taken a stand against protesters on Heirisson Island by backing a plan to shutdown 150 remote Aboriginal communities. Demonstrators have been illegally camping on the island for a week and a half now, saying people will be left homeless.

Abbott is then quoted making a statement (that stimulated international concern in popular and social media):

"What we can't do is endlessly subsidize lifestyle choices if those lifestyle choices are not conducive to the kind of full participation in Australian society that everyone should have".

The subsequent audio and visual segment of the news item problematised the statement. State shadow minister for Aboriginal affairs Ben Wyatt appears, saying: "Native Title demands that Aboriginal people stay on country". While Wyatt continues to speak, the scene cuts to footage of the violent police raid on the Nyoongar Tent Embassy on Heirisson Island in 2012 in a way that suggests that Aboriginal people are right to want to remain on country and that government policy is causing unnecessary trauma and violence. Shots of Heirisson Island are then mixed seamlessly with images from remote communities making it difficult for viewers to distinguish the camp at Heirisson Island (in the Perth metropolis) with footage of remote communities. Producing this ambiguity for viewers places the action outside of familiar cityscapes. Aboriginal country is made remote where popular Australian imaginaries of idealised Aboriginal country safely locate it (Shaw 2007). When the political authorities Bill Shorten, Noel Pearson and Warren Mundine are shown voicing opposition to the closure of communities, these communities are shown to be remote with footage of Aboriginal men sitting on the dirt in a township, children running across a field and women standing amongst trees (Item 2). The voices of authority apparently do not object to City of Perth seeking to shut down the camp on Heirisson Island. This is exemplified in the special fireside report when reporter Scott Cunningham says: 
It's a peaceful protest, they say it's a refugee camp for anyone that's homeless, specifically those displaced by a state government policy that will see 150 remote communities shut down. They have a genuine fear of what will happen. (Item 6)

\section{Fire for community-making}

In 2012, the media held tent embassy members responsible for a social division that it constructed against them, and held them responsible for the state acts of violence that it legitimised against them. The media's law-breaker-protester frame in 2012 not only legitimised the Western Australian government's violence against Aboriginal people, it also excluded relevant state, federal and international laws from news reports about the embassy. This exclusion went unnoticed because of the media's broad failure to recognise Nyoongar Tent Embassy participants as fellow members of 'Perth community': as co-equal citizens. Also, they failed to see that the embassy was open to the public, actively promoting engagement and reconciliation with the wider community of Western Australia. In 2015, popular media authorised voices overcoming such divisions. There was a constructed attempt to represent Aboriginal activists as integrated within a broader community. Although the 2012 gathering was open to the public at most times, only the 2015 gathering was reported as open to the public in popular media. In 2015, the media recognised the gathering as a safe place for people particularly for anyone hoping to engage with Aboriginal culture (by enjoying fireside tradition). From News Item 1 fire is used to suggest Aboriginal people making a stand at Heirisson Island. Footage showed a campfire with Aboriginal people and Aboriginal flags. This becomes an important node for suggesting empathy with camp participants during a major police raid, as reporter Rachel Cary (Item 3) stands by camp participants and explains:

While the police are dismantling the tents, protesters have chosen to stay around this sacred campfire that they have here. The women are in the middle. They say it is a safe spot in case they see a repeat of 2012.

In a live cross to Heirisson Island during the report, Cary says that the elders at the island were: 'glad that police did not touch their campfire which they say is sacred in the middle of the ground and they have had that burning for almost two weeks now'. A week later flag and fire mark the centre of the camp, a position of empathy, after Carey says 'the police will be coming in later this morning' (Item 5).

In the Nine News special report broadcast on March 242015 (Item 6) reporter Scott Cunningham spends the night inside the campsite at Heirisson Island. Cunningham says his purpose is to find 'out what they want and why they are refusing to give up and move on'. The opening scene is a close up of a blazing campfire and a billy, as the camera pans left to show the reporter speaking to Aboriginal activist 'Julie Dwyer' talking about how she and others are sitting around the fire lamenting the closure of communities and what to do about it. The camp, which has now gone on for three weeks, is offered to the viewers as an exception from popular news imagery of an Aboriginal camp. As footage shifts to people sitting around the camp fire with drinks through to a close up of young man mouthing an empty water bottle (which 
may solicit readings of glue-sniffing) the audience is told: 'It's a dry camp. No alcohol, no drugs, and children who stay here still go to school'. Later Julie Dwyer is described as arriving from Geraldton the previous night to show her support to save remote indigenous communities: "They have been there for years, it is their land, it is their culture, it is a spiritual connection to their soul, their heart, their families". In the middle of the piece Cunningham describes how he came to join the fire-side discussion: 'We arrived at six o'clock last night, eventually invited in and allowed to pitch a tent and sit with them by the campfire'. By the fireside, Cunningham informs viewers 'the area is culturally significant as is what they are doing there, their cause reaching all walks of life'. The piece is closed by Scott Cunningham away from the fire saying: 'most of the people have gone to bed in their tents after spending a night around the campfire sharing their stories and reasons why they are here on Heirisson Island'. The footage then cuts to a morning scene, with a close up of a pot on a fire being stoked by a camp participant while Cunningham says 'by morning they are back around the campfire to start their next day on Heirisson Island welcoming in anyone who wants to join their fight'. A final word is offered by an unnamed camp participant saying "people are losing their homes, that's what made me come out here" (Item 6). This news report confirms the shift in Nine News' reporting of the 2015 gathering. Gone are the constructed social divisions overcome via a meeting around the safety of the Heirisson Island campfire.

Between March 24 (Item 6) and the next report in the archive on April 30 (Item 7), a groundswell of public concern over remote community closures was demonstrated by a large rally on April 9 in Melbourne. With May Day rally's planned across Australia, focusing on opposition to remote community closures, Nine News (item 7) reported on April 30:

Another show of force on Heirisson Island today as dozens of police again moved in to break up the protesters' camp. Amid the angry clashes and arrests, accusations some officers were being heavy handed.

Throughout this footage of police arresting camp participants and removing equipment, the viewer is asked to empathise with camp participant perspectives and see the absurdity in the police arrests and issuances of move on notices. The report closes with a reporter standing outside the camp at night saying:

After police left, several protesters set up camp again. There are about five tents here, they have got a campfire going and plan to stay here again tonight. They say that more people will join them later this evening and tomorrow. (Item 7)

The suggested empathy with and rationality of joining a movement to protest government policy is continued in Item 8. After various shots of the May Day demonstration in the Perth CBD and outside parliament, footage cuts to a night scene of a tent and blazing campfire with the reporter saying 'tents are still standing at Heirisson Island' (Item 8). 


\section{Campfire not a homefire}

The campfire on Heirisson Island functioned as an important node for communitymaking in the 2015 Nine News archive, however it was not represented as a place of home or Aboriginal sovereignty. Similarly, in 2012 media workers, politicians and governmental spokesmen failed to see that embassy members were at home in the state-listed Aboriginal heritage site within a native-title claim area, recognised by the Federal Court of Australia. They failed to hear the tent embassy's repeated efforts to engage in direct dialogue with state and city authorities about its at-home status. In 2015 this elision was maintained. Item 2 announces:

Time is running out for protesters taking a stand on Heirisson Island. They have been given a deadline to leave or be forced out by police.

Flag and fire may suggest an Aboriginal place at Heirisson Island, but this place is rendered temporary by the report as the authority of the City of Perth's CEO is reinforced:

Protesters are illegally camping on City of Perth land, they say this is a refugee camp for those made homeless by state government plans to close 150 remote communities. (Item 2)

The problem, again, seems to lie in the representation of 'protesters'. Carey's empathy (Item 3 and 5) is with 'protesters', not self-determined Aboriginal people on their own land. This supports the rationality of her saying that the City of Perth 'will not be removing protesters themselves unless they break the law' (Item 5). For in this representation, protesters are always on the cusp of breaking the law. Even when Cunningham reports from the fireside, he does not question the authority of police or the state to move Aboriginal campers out of the city. Also, the Nyoongar place name 'Matagarup' is not mentioned in his report (Item 6). The closest the special report comes to recognising Aboriginal people at home is through Cunningham's statement: 'the area is culturally significant as is what they are doing there, their cause reaching all walks of life' (Item 6). Although the culturally significant area could have been read as Matagarup, the subsequent opinion of a non-Aboriginal man by the fireside was likely to have been read as maintaining Aboriginal home outside the city: "listening to these guys who have got family and stuff up there and what they are going through, and how important country is to them, and what it means to be put off country is something that I think our culture really struggles to understand". The speaker is identified in subtext as Matt Crocky who "joined the cause". The news item reproduced a growing discourse of concern about the closure of remote communities in Western Australia. Despite soliciting audience empathy with Aboriginal people in remote communities, the item does not solicit empathy for Aboriginals in Perth. When local Aboriginal activist Bella Bropho is on camera earlier in the piece, she is introduced with Cunningham's question: "How long do you think you guys will be down here for?" Bella responds: "I don't really know." Bella Bropho is already known by many media workers in Perth as a key activist voicing concern over the bulldozing of the Swan Valley Nyungah Community at Lockridge in the Perth metropolitan area. A year earlier, Bella Bropho was reported by ABC News (2014) saying in relation to her community's ownership of the land at Lockridge that 'the 
government is intensively trying to destroy the last visible vestiges of what was a thriving community'. In the Nine News report the dialogic of the fireside at Matagarup was fabricated for audience consumption without reference to the site being an enduring Aboriginal place in the city. Instead permanency is given to the European place name Heirisson Island while temporality is associated with Aboriginal presence at an apparently non-urban island.

\section{Conclusion}

This paper argues that the Matagarup campfire in Perth city functioned as an important node for community-making, enabled through broad cultural understandings of what a campfire might symbolise. Representation of the campfire marked a significant shift in media reporting for at least one popular news organisation, Nine News. Media audiences were invited to engage with the sacralisation of the campfire through the reporting of a major police raid where the campfire was represented as a safe zone for participants, and again a week later as audiences got to share in the fireside stories with Nine News reporter Scott Cunningham. However, despite the marked shift in media reporting of the 2015 gathering compared to the 2012 Nyoongar Tent Embassy, the politics of belonging at Matagarup remained unchallenged in popular television news. The media dialogic authorising heritage making may have constrained the violence of police responses to the 2015 Aboriginal gathering at Matagarup but it also limited popular understanding of this event to a temporary gathering of outsiders who should move on once government policy had improved.

\section{References}

ABC News. 2014. "Swan Valley Nyungah Community cleared to create conservation reserve and meeting place". ABC News March 18, 2014. Viewed on 8 June 2015 http://www.abc.net.au/news/2014-03-18/swan-valley-nyungahcommunity-camp-cleared-for-reserve/5328756

Aboriginal Heritage Inquiry System. 2012. Site 3589. Perth: Government of Western Australia, Department of Indigenous Affairs. http://www.dia.wa.gov.au/AHIS/default.aspx

Australian War Memorial, n.d., Eternal Flames in Australia, Canberra: Government $\begin{array}{lllll}\text { of } & \text { Australia. } & \text { Accessed } & \text { May } & 22\end{array}$ https://www.awm.gov.au/encyclopedia/eternal_flame/flames_aust/

Bindon, Peter and Ross Chadwick. 2011. A Nyoongar Wordlist: From the South-West of Western Australia. Perth: Western Australian Museum.

Botanic Gardens \& Parks Authority. 2015. State War Memorial, May 14, Perth: Government of Western Australia. Accessed May 222015 http://www.bgpa.wa.gov.au/kings-park/visit/history/state-war-memorial

Buckland, Adelene. 2009. "Pictures in the Fire': the Dickensian Hearth and the Concept of History," Romanticism and Victorianism on the Net, 53: 
http://www.erudit.org/revue/ravon/2009/v/n53/029902ar.html,

doi: 10.7202/029902ar

Creagh, R., Ryder, P., Cox, S. \& Kerr, T. (2013, July). I'm not going anywhere. I'm here all the time. Exhibition of visual works at the State Library of Western Australia for NAIDOC Week.

Gelder, Ken \& Jacobs, Jane, 1995. "'Talking out of place': Authorizing the Aboriginal sacred in postcolonial Australia”, Cultural Studies, 9(1): 150-160. doi: 10.1080/09502389500490291

Gilbert, Eleanor, 2013, "extracts from 'Fire Creator for Justice is Awoken"” in The Aboriginal Tent Embassy: Sovereignty, Black power, Land Rights and the State, edited by G. Foley, A. Schaap and E. Howell. Florence: Taylor and Francis.

Hallam, Sylvia J. 1975. Fire and Hearth: a Study of Aboriginal Usage and European Usurpation in South-western Australia. Canberra: Australian Institute of Aboriginal Studies.

Jones, Tod and Collard, Len. 2014. Karla Yarning: Stories of the Home Fires. Perth: City of Perth.

Kerr, T. \& Cox, S. (2016). "Media, Machines and Might: Reproducing Western Australia's Violent State of Aboriginal protection". Somatechnics, 6 (1): 89105, doi: 10.3366/soma.2016.0176.

Laclau, Ernesto, 2005. On Populist Reason. London: Verso.

Nine Entertainment Co. Holdings, 2014. Nine Entertainment Co.: Annual Report 2014. Sydney. Accessed May $22 \quad 2015$ http://www.nineentertainment.com.au/media/3771/NEC-Annual-Report-2014web-.pdf

Shaw, Wendy. 2007b. "Fixed Traditions and Locked-up Heritages: Misrepresenting Indigeneity." Chapter 7 In Geographies of Australian Heritages: Loving a Sunburnt Country?, edited by Roy Jones and Brian Shaw, 95-112. Aldershot: Ashgate.

Statham-Drew, Pameal, 2003. James Stirling: admiral and founding governor of Western Australia, Nedlands: UWA Press.

Thomson, Chris, Dawn Bennett, Michelle Johnston and Bonita Mason. 2015. "Why the Where Matters: A Sense of Place Imperative for Teaching better Indigenous Affairs Reporting”. Pacific Journalism Review 21 (1): 141-161.

Vincent, Eve. 2006. "Around the Fire”. Arena Magazine 83 (June-July): 13-14.

Willmert, Todd. 2006. "The 'ancient fire, the hearth of tradition': combustion and creation in Le Corbusier's studio residences." Arq: Architectural Research Quarterly 10(1): 57-78.

Wynne, Emma. 2014. "Mapping Noongar Perth: new guide details Indigenous history in the CBD". $A B C$ News Accessed May 142015 from http://www.abc.net.au/news/2014-07-11/noongar-maps-of-perth-cityreleased/5589910

Dr Shaphan Cox is a human geographer in the Department of Planning and Geography at Curtin University, Western Australia. His research explores contestations of space and place through representation. Recent publications include the book Setting up the Nyoongar Tent Embassy, co-authored with Dr Thor Kerr, and the article "Indigenous persistence and entitlement: Noongar occupations in central Perth, 1988-1989 and 2012." 
Coolabah, No.21, 2017, ISSN 1988-5946, Observatori: Centre d'Estudis Australians / Australian Studies Centre, Universitat de Barcelona

Dr Thor Kerr is a lecturer in the Department of Communication and Cultural Studies at Curtin University, Western Australia. Dr Kerr's research focuses on media and public representation in negotiations of urban space, particularly in relation to environmental issues, colonisation and Aboriginal heritage. His latest book, To the Beach, examines public controversy and policy making around 'sustainable' coastal property development. His previous (co-authored) book, Setting up the Nyoongar Tent Embassy: a Report on Perth Media, investigated the systemic shaping of popular news reports that criminalised Aboriginal activists. 